\title{
Igneous Pyroxenes From Metamorphosed Anorthosite Massifs*
}

\author{
S.R. Bohlen and E.J. Essene \\ Department of Geology and Mineralogy, The University of Michigan, Ann Arbor, Michigan, U.S.A.
}

\begin{abstract}
Anorthosites, mangerites and charnockites from metamorphosed anorthosite massifs (the Adirondacks and elsewhere) commonly contain coarsely exsolved pyroxenes with substantial amounts of exsolved orthopyroxene (in clinopyroxene) and clinopyroxene (in orthopyroxene). Electron microprobe reintegration of such pyroxenes yields compositions which indicate that pigeonite and subcalcic augite coexisted before metamorphic reequilibration. Equilibration temperatures of $1100^{\circ} \pm 100^{\circ} \mathrm{C}$ for anorthosite and $1000^{\circ} \mathrm{C} \pm 100^{\circ} \mathrm{C}$ for mangerites and charnockites are inferred from the solvus of Ross and Huebner (1975). These temperatures constrain minimum magmatic thermal conditions and suggest that the magmas were relatively dry. Exsolution lamellae of coarse pyroxenes and small equant coexisting pyroxenes (with little or no exsolution) yield temperatures of $\leqq 750^{\circ} \mathrm{C}$, consistent with equilibration during granulite facies metamorphism. Relict igneous textures and compositions persisted through the metamorphic event due to dry $P\left(\mathrm{H}_{2} \mathrm{O}\right) \ll P($ solid $)$ metamorphic conditions. The reintegrated pyroxene compositions provide a window through the metamorphism and yield constraints on the pre-metamorphic igneous events.
\end{abstract}

\section{Introduction}

Despite the lack of extensive experimental data within the pyroxene quadrilateral the compositions of coexisting $\mathrm{Ca}$-rich and $\mathrm{Ca}$-poor pyroxenes have often been used to estimate equilibration temperatures. The distribution coefficients $\mathrm{Ca} /\left(\mathrm{Mg}+\mathrm{Fe}^{2+}\right)$ and $\mathrm{Fe}^{2+} / \mathrm{Mg}$

\footnotetext{
* Contribution No. 340 from the Mineralogical Laboratory, Department of Geology and Mineralogy, The University of Michigan, Ann Arbor, Michigan, 48109, U.S.A.
}

between the pyroxenesare both sensitive to temperature. The pyroxene thermometers have been applied to igneous and metamorphic rocks with varying degrees of success. Binns (1962) used natural pyroxene pairs to determine a pyroxene solvus for Australian granulites. Davidson (1968) attempted to infer metamorphic temperatures from another granulite terranes relative to Binns' (1962) data. Davidson (1968) also demonstrated that $\mathrm{K}_{D}\left(\mathrm{Fe}^{2+} / \mathrm{Mg}\right)^{1}$ changes by up to 0.2 with the pyroxene composition and offered a crystal-chemical explanation for this secondary effect.

Because of the many difficulties in determining equilibration temperatures in rocks from independent thermometers, fieled calibration of the pyroxene solvus is exceedingly difficult. Consequently many workers have devoted much effort to experimental calibration of the system. Lindsley et al. (1974) investigated the pyroxene system at $810^{\circ} \mathrm{C}$ and attempted reversed equilibria. Reversals were not achieved due to sluggish reaction rates. Many other workers, including Davis and Boyd (1966), Lindsley and Munoz (1969), Grover et al. (1972), Smith (1972), Lindsley et al., (1973), Lindsley et al. (1974), Nehru and Wyllie (1974), Warner and Luth (1974) and Mori and Green (1975) have experimentally investigated portions of the pyroxene quadrilateral. Most of the experiments by these investigators were attempted above $1000^{\circ} \mathrm{C}$ and at elevated pressure to promote reaction rates. Extrapolation to lower temperatures involves substantial uncertainty. Because of difficulties with low temperature extrapolations as well as problems of order-disorder and additional components, the pyroxene thermometer is poorly calibrated for natural systems at temperatures below $1000^{\circ} \mathrm{C}$. Consequently, it is of limited value in metamorphic terranes. The pyroxene thermometer has been applied with greater

\footnotetext{
1 The $K_{D}$ is here defined as the ratio of $\mathrm{Fe}^{2+} / \mathrm{Mg}$ between coexisting $\mathrm{Ca}$-poor and $\mathrm{Ca}$-rich pyroxenes
} 
success in igneous rocks. Recently Wood and Banno (1973) have proposed a thermodynamic model to account for additional components in natural pyroxene pairs, and Wood (1975) has applied it to granulites at South Harris, Scotland. As yet, their thermometer based upon coexisting pyroxenes has not been carefully evaluated in areas where temperatures have been obtained using independent thermometers.

Despite the many difficulties in experimental calibration of the system, coexisting ortho- and clinopyroxenes can be used qualitatively to distinguish the equilibration temperatures in different rocks which equlibrated at substantially different temperatures. For instance, the system can be used to distinguish pyroxene pairs which equilibrated at igneous temperatures from those which equilibrated at metamorphic temperatures. Semi-quantitative data of this type may prove valuable in constraining models on the sequence of events in a given metamorphic terrane.

\section{Adirondack Pyroxenes}

Coexisting ortho- and clinopyroxenes are ubiquitous in the garnet-granulite facies terrane of the Adirondack Highlands in Upper New York State. During a continuing study of regional metamorphism in the Adirondacks several texturally distinct pyroxenes have been observed in metamorphosed igneous rocks. A large variety of rock types ranging in composition from anorthosite and anorthositic gabbros to mangerites and charnockites often contain coarse (up to $3 \mathrm{~cm}$ ) clino- and orthopyroxene phenocrysts which contain coarse (up to $25 \mu$ wide) exsolution lamellae (Fig. 1). In anorthosite these pyroxenes are typically intergrown with plagioclase in ophitic or subophitic textures. In mangerites and charnockites they are usually microphenocrysts. Coarsely exsolved orthorhombic and monoclinic pyroxenes commonly coexist in many anorthosites, mangerites, and charnockites. Substantial amounts of exsolved augite are contained in orthopyroxenes and hypersthene in clinopyroxene (Fig. 1). Although the coarse low calcium pyroxene is now an orthopyroxene host, average analysis of these pyroxene grains (Table 1) yield 7-10 mole \% Wo component. This indicates that they were once pigeonites which have subsequently changed to a mixture of ortho- and clinopyroxene. Similarly, reintegrated coarse clinopyroxene analyses (Table 1) clearly indicate that the grains were very subcalcic augites before a low-calcium phase exsolved from them. Very small amounts of Fe-oxide, typically ilmenite, occur as thin "exsolution" lamellae in both ortho- and clinopyroxene. In the same rocks with the exsolved pyroxenes are equant ortho- and clinopyroxenes which contain, at most, minor fine exsolution lamellae or no exsolution products at all (Fig. 1). These pyroxenes are often found growing around the coarse pyroxenes as small equant granules. Also, they are frequently found intergrown with granulated plagioclase, quartz and a variety of other phases with textures typical of metamorphic rocks. Generally these pyroxenes are considerably smaller than the coarsely exsolved pyroxenes, although there is some overlap in size. Pyroxenes containing little or no exsolution are not restricted to rocks with coarsely exsolved pyroxenes, but are ubiquitous in the granulite facies of the Adirondacks, east and southeast of the orthopyroxene isograd mapped by Engel and Engel (1962).

In addition to the pyroxenes described above, anorthositic rocks in the Elizabethtown (Emslie, written communication), Mount Marcy, and Long Lake quadrangles also contain two types of pyroxene megacrysts. One occurs as bronze to khaki-colored orthopyroxene crystals up to $8 \mathrm{~cm}$ in maximum dimension. These contain substantial amounts of exsolved plagioclase (An 85) and magnetite. This megacryst type is found in other anorthosite massifs and has been investigated by Emslie (1975) and Morse (1975). Though Emslie (1975) has occasionally found coexisting ortho- and clinopyroxenes with exsolved plagioclase in the Morin complex of Canada, only orthopyroxenes with exsolved plagioclase have been found so far in the Adirondacks. The second type of pyroxene megacryst occurs as very large (up to $0.5 \mathrm{~m}$ ) black crystals in a typical anorthosite matrix. They are orthopyroxenes with minor exsolved clinopyroxene. They differ from other Adirondack pyroxenes not only in morphology, but also in their chemistry; they are substantially more magnesium-rich than other Adirondack pyroxenes. Sample localities of rocks containing pyroxenes which are discussed in this paper are shown in Figure 2. Sample locality descriptions are compiled in Appendix I.

\section{Analytical Procedure}

Quantitative electron microprobe analyses were obtained in order to interpret the significance of the several Adirondack pyroxene types. Major and minor element analyses were obtained using an ARL-EMX electron microprobe analyzer with wavelength dispersive PET, LiF, and TAP crystal spectrometers. An accelerating potential of $15 \mathrm{keV}$ and an emission current of $150 \mu$ A were standard operating conditions. Sample current was typically $.005-$ $.008 \mu \mathrm{A}$. Beam current was digitized with counting times of $25-35 \mathrm{~s}$ for each point analyzed. For homogeneous unknowns spectrometer data were taken on 5 different points on a single grain and were averaged to obtain an analysis. Obtaining average analyses of coarsely exsolved pyroxenes is discussed in detail below. Natural, well-analyzed almandine-rich garnet (Ingamells, unpublished), Alrich clinopyroxene (Irving, written comm.), Fe-rich kaersutite (Irv- 


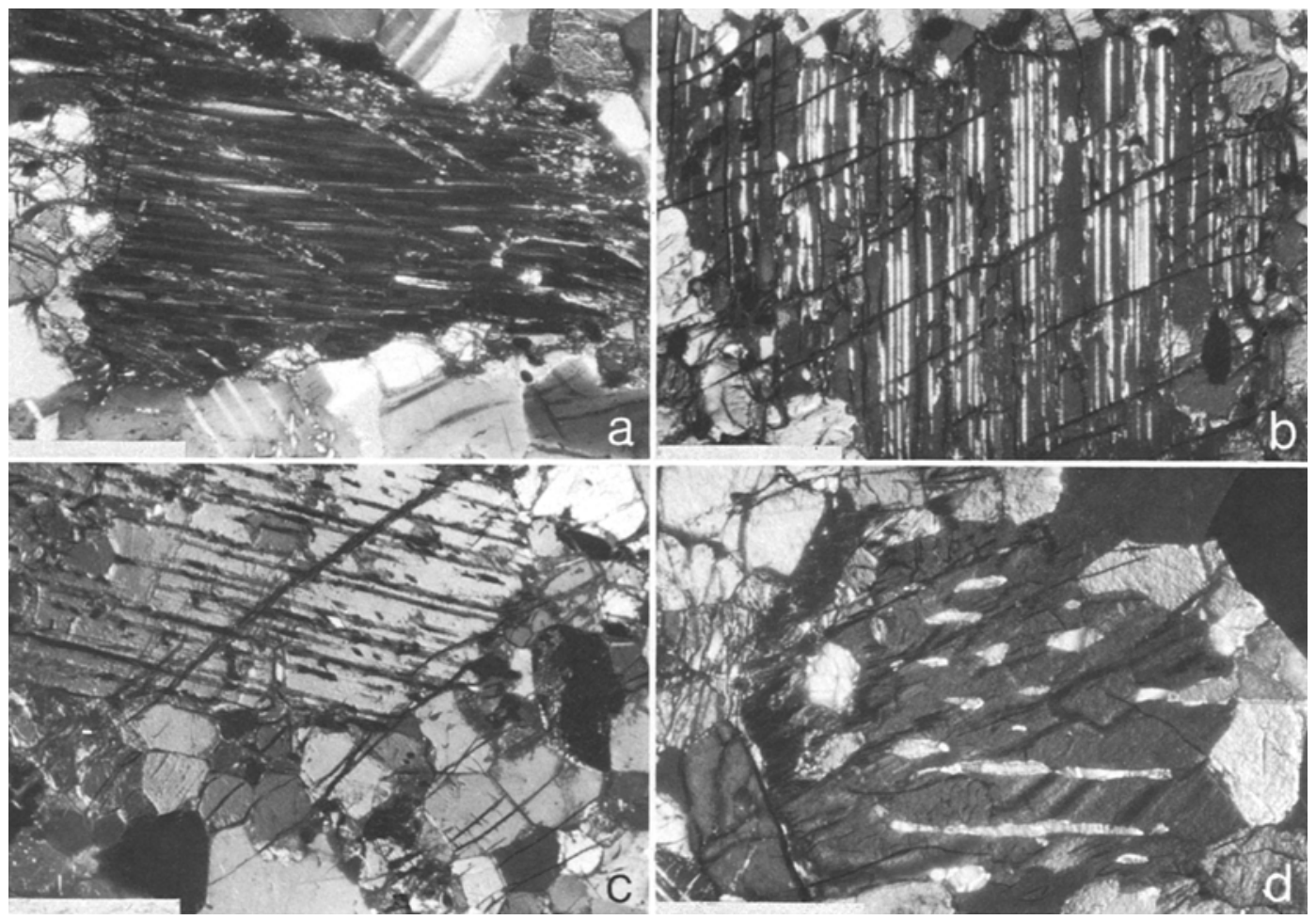

Fig. 1a. Inverted pigeonite. Note the substantial amount of exsolved clinopyroxene. b Clinopyroxene host showing extensive orthopyroxene exsolution. $\mathbf{c}$ Equant granules of ortho- and clinopyroxene surrounding a coarsely exsolved clinopyroxene. d Blebby exsolution in inverted pigeonite. Note the extension of portions of external pyroxene granules into the orthopyroxene host. All views under crossed polars. Bar scales are $1.0 \mathrm{~mm}$

ing, Lunar Sci. Inst., written comm.) anorthoclase (Kerrick, Penn St., written comm.), labradorite (Kerrick, Penn St., written comm.) and anorthite (Evans, U. Wash., written comm.) were used as probe standards. Spectrometer data were corrected for atomic number, fluorescence and absorption effects using the Fortran program EMPADR VII written by Rucklidge and Gasparrini (1969). All major and minor elements in each of the phases were identified by obtaining emission spectra using an energy dispersive $\mathrm{Li}$-doped silicon crystal and a multi-channel analyzer over a 1000 s counting period under conditions which easily allow detection of heavy elements $(\geqq \mathrm{Na})$ at levels of $0.1 \mathrm{wt} \%$. Special care was taken to detect such elements as $\mathrm{Cr}, \mathrm{Zn}$ (up to $0.5 \mathrm{wt} . \% \mathrm{ZnO}$ was reported in Fe-rich Adirondack pyroxenes by Jaffe et al., 1975), and Ni. Spectrometer data were obtained for these elements, but together they constitute less than $0.1 \mathrm{wt} \%$ of any pyroxene reported here.

Since the coarsely exsolved pyroxenes and pyroxene megacrysts with exsolution of augite and plagioclase most certainly represent reequilibrated meterials, the significance of these pyroxenes can only be correctly interpreted by obtaining an original homogeneous composition. It is clear from the description in a paper by Jaffe et al. (1975) that care was not taken to account for exsolution lamellae in microprobe analyses of pyroxenes from the Adirondacks. This may explain their erratic $K_{D}\left(\mathrm{Fe}^{2+} / \mathrm{Mg}\right)$ values and may well have adversely affected their interpretations. In order to obtain average, reintegrated analyses of exsolved pyroxenes the microprobe beam was defocussed to approximately $25 \mu$ and between 200 and 400 points were analyzed such that spectrometer data were taken on a substantial, representative area of exsolved pyroxene. The data are then averaged to obtain an original unexsolved composition. The lamellae have been analyzed separately when possible. For one specimen, LL-8, the rock was cut in several different orientations and a number of pyroxene reintegrations were undertaken on grains of different orientation. The data are plotted in Figure 3 and compiled in Appendix II. It can be seen that the variation in reintegrated analyses is not large, with errors on the order of of $\pm 1 \mathrm{~mol} \% \mathrm{Ca}-\mathrm{Mg}-\mathrm{Fe}$. Reintegration can be complicated by the effects of diffusion during annealing. Annealing can cause blebby to granular and erratic exsolution, and greater care must be taken to insure a representative, average analysis. Grain boundary diffusion can reduce the amount of exsolved material remaining, thus changing the inferred composition. Frequently there are external granules which have extensions into the host phase as blebby exsolved lamellae (Fig. 1). These textures appear to represent intermediate stages between exsolution and complete reequilibration as two separate grains and are simply avoided for reintegration.

Ferric iron was not determined directly but instead was inferred from stoichiometry. Direct determination of $\mathrm{Fe}^{2+} / \mathrm{Fe}^{3+}$ was not attempted because these values may well have been reset during the complicated exsolution process. The estimation of $\mathrm{Fe}^{2+}$ $\mathrm{Fe}^{3+}$ requires normalization about four cations and maintaining charge balance by converting $\mathrm{Fe}^{2+}$ to $\mathrm{Fe}^{3+}$. Therefore for pyroxenes $\mathrm{Fe}_{\text {(total) }}=\Sigma \mathrm{Fe}^{2+}+\mathrm{Fe}^{3+}$ and $\mathrm{Fe}^{3+}=\mathrm{Al}^{\mathrm{rv}}-\mathrm{Al}^{\mathrm{Vl}}+\mathrm{Na}+\mathrm{K}-2 \mathrm{Ti}$. This technique is critically dependent on careful elemental analyses, especially for $\mathrm{Si}$ and $\mathrm{Al}$ and assumes an initially stoichiometric pyroxene. For pyroxene quadrilateral plots and $K\left(\mathrm{Fe}^{2+} / \mathrm{Mg}\right)$ calculations in this paper only $\mathrm{Fe}^{2+}$ was considered. However, the results are not altered significantly by consideration of total $\mathrm{Fe}$ or for total $\mathrm{Fe}+\mathrm{Mn}$. Since non-quadrilateral components (involving $\mathrm{Al}^{\mathrm{IV}}, \mathrm{Al}^{\mathrm{VI}}, \mathrm{Ti}, \mathrm{Fe}^{3+}, \mathrm{Mn}, \mathrm{Na}, \mathrm{K}$ ) are typically less than 10 mole $\%$, pyroxenes from the Adirondacks can be adequately represented on the standard pyroxene quadrilateral. 
Table 1. Pyroxene analyses

\begin{tabular}{|c|c|c|c|c|c|c|c|c|c|c|c|c|c|c|c|c|c|c|}
\hline & $\begin{array}{l}\text { LL-8 } \\
\text { Intg. } \\
\text { Opx }\end{array}$ & $\begin{array}{l}\text { LL-8 } \\
\text { Intg. } \\
\mathrm{Cpx}\end{array}$ & $\begin{array}{l}\text { LL-8 } \\
\text { Opx } \\
\text { Host }\end{array}$ & $\begin{array}{l}\text { LL-8 } \\
\text { Opx } \\
\text { in } \\
\text { Cpx }\end{array}$ & $\begin{array}{l}\text { LL-8 } \\
\text { Cpx } \\
\text { Host }\end{array}$ & $\begin{array}{l}\text { LL-8 } \\
\text { Meta. } \\
\text { Opx }\end{array}$ & $\begin{array}{l}\text { LL-8 } \\
\text { Meta. } \\
\text { Cpx }\end{array}$ & $\begin{array}{l}\text { 77-SL-2 } \\
\text { Intg. } \\
\text { Opx }\end{array}$ & $\begin{array}{l}\text { 77-SL-2 } \\
\text { Intg. } \\
\text { Cpx }\end{array}$ & $\begin{array}{l}\text { 77-SL-2 } \\
\text { Opx } \\
\text { in } \\
\text { Cpx }\end{array}$ & $\begin{array}{l}\text { 77-SL-2 } \\
\text { Cpx } \\
\text { in } \\
\text { Opx }\end{array}$ & $\begin{array}{l}\text { 77-SL-2 } \\
\text { Meta. } \\
\text { Opx }\end{array}$ & $\begin{array}{l}\text { 77-SL-2 } \\
\text { Meta. } \\
\text { Cpx }\end{array}$ & $\begin{array}{l}\text { IN-11 } \\
\text { Intg. } \\
\text { Opx }\end{array}$ & $\begin{array}{l}\text { IN-11 } \\
\text { Intg. } \\
\text { Cpx }\end{array}$ & $\begin{array}{l}\text { IN-11 } \\
\text { Opx } \\
\text { Host }\end{array}$ & $\begin{array}{l}\text { IN-11 } \\
\text { Cpx } \\
\text { in } \\
\text { Opx }\end{array}$ & $\begin{array}{l}\text { IN-11 } \\
\text { Opx } \\
\text { in } \\
\text { Cpx }\end{array}$ \\
\hline $\mathrm{SiO}_{2}$ & 49.67 & 49.80 & 50.67 & 50.52 & 50.73 & 52.17 & 50.85 & 49.88 & 50.27 & 50.02 & 50.60 & 49.60 & 50.18 & 45.82 & 47.98 & 47.85 & 49.15 & 46.56 \\
\hline $\mathrm{TiO}_{2}$ & 0.18 & 0.76 & 0.08 & 0.17 & 0.25 & 0.04 & 0.41 & 0.17 & 0.42 & 0.09 & 0.39 & 0.08 & 0.38 & 0.11 & 0.12 & 0.11 & 0.20 & 0.11 \\
\hline $\mathrm{Al}_{2} \mathrm{O}_{3}$ & 2.99 & 3.95 & 1.90 & 1.50 & 2.97 & 1.28 & 3.14 & 2.44 & 2.76 & 1.77 & 3.35 & 1.62 & 3.57 & 0.80 & 1.15 & 0.48 & 1.20 & 0.29 \\
\hline $\mathrm{FeO}^{2}$ & 23.90 & 14.01 & 26.08 & 27.82 & 10.15 & 26.68 & 10.38 & 25.16 & 15.80 & 29.08 & 11.12 & 29.69 & 12.07 & 45.20 & 31.67 & 43.65 & 23.01 & 43.84 \\
\hline $\mathrm{MnO}$ & 0.44 & 0.31 & 0.51 & 0.54 & 0.29 & 0.65 & 0.26 & 0.36 & 0.24 & 0.29 & 0.19 & 0.33 & 0.22 & 0.81 & 0.64 & 1.49 & 0.64 & 1.46 \\
\hline $\mathrm{MgO}$ & 17.90 & 13.24 & 19.29 & 18.77 & 12.58 & 18.66 & 12.12 & 15.82 & 11.57 & 16.75 & 11.59 & 16.36 & 10.90 & 3.06 & 5.30 & 5.86 & 5.23 & 5.88 \\
\hline $\mathrm{CaO}$ & 3.78 & 16.31 & 0.41 & 0.48 & 21.87 & 0.44 & 21.74 & 4.23 & 17.31 & 0.51 & 22.04 & 0.57 & 21.77 & 3.26 & 12.03 & 0.51 & 20.45 & 0.82 \\
\hline $\mathrm{Na}_{2} \mathrm{O}$ & 0.06 & 0.41 & $<0.03$ & $<0.03$ & 0.39 & $<0.03$ & 0.48 & 0.19 & 0.65 & $<0.03$ & 0.76 & $<0.03$ & 0.82 & 0.05 & 0.56 & $<0.03$ & 0.58 & $<0.03$ \\
\hline $\mathrm{K}_{2} \mathrm{O}$ & $<0.03$ & $<0.03$ & $<0.03$ & $<0.03$ & $<0.03$ & $<0.03$ & nd & $<0.03$ & $<0.03$ & $<0.03$ & $<0.03$ & $<0.03$ & $<0.03$ & $<0.03$ & $<0.03$ & $<0.03$ & $<0.03$ & $<0.03$ \\
\hline SUM & 98.93 & 98.80 & 98.95 & 99.82 & 99.24 & 99.94 & 99.38 & 98.26 & 99.03 & 98.53 & 100.1 & 98.26 & 99.92 & 99.12 & 99.46 & 100.0 & 100.5 & 98.97 \\
\hline $\mathrm{Si}$ & 1.900 & 1.896 & 1.941 & 1.931 & 1.912 & 1.990 & 1.918 & 1.942 & 1.928 & 1.957 & 1.897 & 1.951 & 1.892 & 1.951 & 1.952 & 2.000 & 1.940 & 1.970 \\
\hline $\mathrm{Al}$ & 0.100 & 0.104 & 0.059 & 0.068 & 0.088 & 0.010 & 0.082 & 0.058 & 0.072 & 0.043 & 0.103 & 0.049 & 0.109 & 0.048 & 0.048 & 0.000 & 0.056 & 0.014 \\
\hline $\mathrm{Al}$ & 0.035 & 0.073 & 0.027 & 0.000 & 0.044 & 0.047 & 0.057 & 0.054 & 0.053 & 0.038 & 0.045 & 0.026 & 0.049 & 0.000 & 0.007 & 0.024 & 0.000 & 0.000 \\
\hline $\mathrm{Ti}$ & 0.005 & 0.022 & 0.002 & 0.005 & 0.007 & 0.001 & 0.012 & 0.005 & 0.012 & 0.012 & 0.011 & 0.002 & 0.011 & 0.003 & 0.004 & 0.004 & 0.006 & 0.004 \\
\hline $\mathrm{Fe}^{3+}$ & 0.061 & 0.018 & 0.028 & 0.062 & 0.059 & 0.000 & 0.037 & 0.009 & 0.042 & 0.000 & 0.091 & 0.020 & 0.097 & 0.050 & 0.077 & 0.000 & 0.096 & 0.039 \\
\hline $\mathrm{Mg}$ & 1.021 & 0.752 & 1.102 & 1.070 & 0.707 & 1.061 & 0.683 & 0.918 & 0.662 & 0.977 & 0.648 & 0.959 & 0.612 & 0.369 & 0.322 & 0.365 & 0.308 & 0.371 \\
\hline $\mathrm{Fe}^{2+}$ & 0.703 & 0.428 & 0.808 & 0.826 & 0.261 & 0.851 & 0.290 & 0.810 & 0.465 & 0.951 & 0.258 & 0.957 & 0.283 & 1.362 & 1.000 & 1.527 & 0.664 & 1.512 \\
\hline $\mathrm{Mn}$ & 0.014 & 0.010 & 0.016 & 0.017 & 0.009 & 0.021 & 0.008 & 0.012 & 0.008 & 0.010 & 0.006 & 0.011 & 0.007 & 0.047 & 0.022 & 0.053 & 0.021 & 0.052 \\
\hline $\mathrm{Ca}$ & 0.155 & 0.666 & 0.017 & 0.019 & 0.884 & 0.018 & 0.878 & 0.177 & 0.711 & 0.021 & 0.886 & 0.024 & 0.879 & 0.164 & 0.524 & 0.023 & 0.865 & 0.037 \\
\hline $\mathrm{Na}$ & 0.005 & 0.030 & 0.000 & 0.001 & 0.029 & 0.001 & 0.035 & 0.015 & 0.047 & 0.000 & 0.055 & 0.001 & 0.060 & 0.006 & 0.044 & 0.002 & 0.044 & 0.001 \\
\hline $\mathrm{K}$ & 0.001 & 0.001 & 0.000 & 0.001 & 0.000 & 0.000 & nd & 0.000 & 0.000 & 0.000 & 0.000 & 0.000 & 0.001 & 0.001 & 0.000 & 0.002 & 0.000 & 0.000 \\
\hline Wo & 8.2 & 36.1 & 0.8 & 0.9 & 47.7 & 0.9 & 47.5 & 9.3 & 38.7 & 1.1 & 49.4 & 1.3 & 49.5 & 8.7 & 28.4 & 1.2 & 47.1 & 1.9 \\
\hline En & 54.4 & 40.7 & 57.3 & 55.9 & 38.2 & 55.0 & 36.9 & 48.2 & 36.0 & 50.1 & 36.2 & 49.4 & 34.5 & 19.4 & 17.4 & 19.1 & 16.8 & 19.3 \\
\hline Fs & 37.4 & 23.2 & 41.9 & 43.2 & 14.1 & 44.1 & 15.6 & 42.5 & 25.3 & 48.8 & 14.4 & 49.3 & 16.0 & 71.9 & 54.2 & 79.7 & 36.1 & 78.8 \\
\hline $\mathrm{K}_{\mathrm{D}}$ & \multicolumn{2}{|c|}{1.210} & & \multicolumn{2}{|c|}{2.091} & \multicolumn{2}{|c|}{1.889} & \multicolumn{2}{|c|}{1.265} & \multicolumn{2}{|c|}{2.445} & \multicolumn{2}{|c|}{2.158} & \multicolumn{2}{|c|}{1.189} & \multicolumn{2}{|c|}{1.941} & \\
\hline
\end{tabular}

$\mathrm{Fe}^{3 \div}$ inferred from stoichiometry

a Total iron as FeO. Pyroxenes normalized about 4 cations

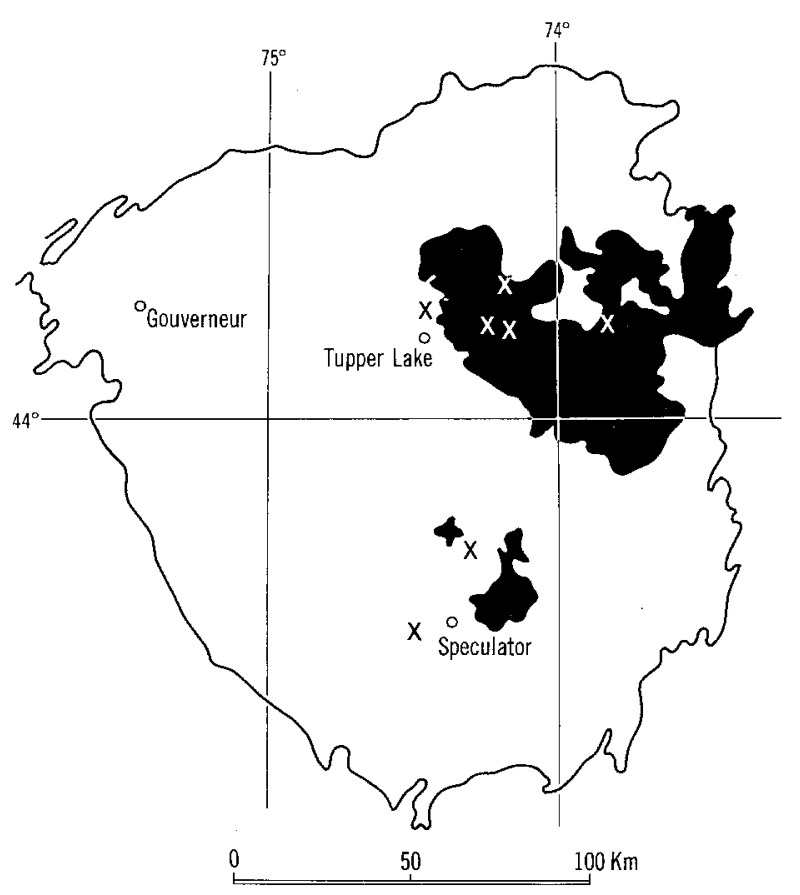

Fig. 2. Outline map of the Precambrian terrane of Upper New York State showing pyroxene sample locations. Anorthosite masses are shown in black

\section{Analytical Results and Discussion}

Data for coarsely exsolved coexisting Adirondack pyroxenes are plotted in Figure 4. The pyroxenes are found in the matrix of anorthosite (LL-8), oxide gabbro (77-SL-2), mangerite (IN-11 and P-10) and charnockite (SR-29). Pyroxenes in mangerite P-10 have been omitted from Figure 4 for the sake of clarity and because of partial retrograde reequilibration of the coarsely exsolved clinopyroxene. Analytical data for pyroxenes are compiled in Table 1. Reintegrated pyroxenes (solid squares), lamellae in exsolved pyroxenes ( $x$ symbols) and unexsolved pyroxenes (solid circles) are plotted on a solvus by Ross and Huebner (1975). The solvus isotherms are based on (1) an Fefree pigeonite and diopside solvus (Kushiro, 1972; Yang, 1973), (2) the augite-pigeonite solvus (Ross et al., 1973) and (3) the granulite facies augite trend. Due to a variety of experimental problems and a lack of experimental reversals, the isotherms can only be approximately located. The location of the augitepigeonite solvus is based on high temperature homogenization of lunar pyroxenes (Ross et al., 1973). It is known from work in other systems that microscopic 


\begin{tabular}{|c|c|c|c|c|c|c|c|c|c|c|c|c|c|}
\hline $\begin{array}{l}\text { IN-11 } \\
\text { Meta. } \\
\text { Opx }\end{array}$ & $\begin{array}{l}\text { IN-11 } \\
\text { Meta. } \\
\text { Cpx }\end{array}$ & $\begin{array}{l}\text { P-10 } \\
\text { Intg. } \\
\text { Opx }\end{array}$ & $\begin{array}{l}\text { P-10 } \\
\text { Intg. } \\
\text { Cpx }\end{array}$ & $\begin{array}{l}\text { P-10 } \\
\text { Opx } \\
\text { in } \\
\text { Cpx }\end{array}$ & $\begin{array}{l}\text { P-10 } \\
\text { Cpx } \\
\text { in } \\
\text { Opx }\end{array}$ & $\begin{array}{l}\text { P-10 } \\
\text { Meta. } \\
\text { Opx }\end{array}$ & $\begin{array}{l}\text { P-10 } \\
\text { Meta. } \\
\text { Cpx }\end{array}$ & $\begin{array}{l}\text { SR-29 } \\
\text { Intg. } \\
\text { Opx }\end{array}$ & $\begin{array}{l}\text { SR-29 } \\
\text { Intg. } \\
\text { Cpx }\end{array}$ & $\begin{array}{l}\text { SR-29 } \\
\text { Opx } \\
\text { in } \\
\text { Cpx }\end{array}$ & $\begin{array}{l}\text { SR-29 } \\
\text { Cpx } \\
\text { in } \\
\text { Opx }\end{array}$ & $\begin{array}{l}\text { SR-29 } \\
\text { Meta. } \\
\text { Opx }\end{array}$ & $\begin{array}{l}\text { SR-29 } \\
\text { Meta. } \\
\text { Cpx }\end{array}$ \\
\hline 47.00 & 49.09 & 47.16 & 48.41 & 46.42 & 48.61 & 47.24 & 48.87 & 45.81 & 47.03 & 44.83 & 47.15 & 44.96 & 48.52 \\
\hline 0.11 & 0.20 & 0.44 & 0.19 & 0.16 & 0.21 & 0.15 & 0.19 & 0.11 & 0.09 & 0.06 & 0.19 & 0.06 & 0.19 \\
\hline 0.34 & 1.56 & 0.73 & 1.27 & 0.20 & 1.05 & 0.29 & 0.97 & 0.80 & 0.96 & 0.30 & 1.00 & 0.38 & 0.97 \\
\hline 44.06 & 23.28 & 40.77 & 27.54 & 43.74 & 22.72 & 43.66 & 22.91 & 45.20 & 35.94 & 49.50 & 27.36 & 48.73 & 23.31 \\
\hline 1.57 & 0.72 & 1.18 & 0.77 & 1.48 & 0.65 & 1.47 & 0.59 & 0.81 & 0.44 & 0.79 & 0.52 & 0.99 & 0.48 \\
\hline 5.89 & 5.14 & 5.61 & 5.02 & 5.46 & 5.03 & 5.89 & 5.13 & 3.06 & 2.88 & 3.06 & 2.82 & 2.95 & 5.09 \\
\hline 0.74 & 19.73 & 3.09 & 14.90 & 0.54 & 20.13 & 0.71 & 20.04 & 3.26 & 11.46 & 0.72 & 19.62 & 0.68 & 19.88 \\
\hline$<0.03$ & 0.58 & 0.37 & 0.55 & 0.88 & 0.69 & $<0.03$ & 0.72 & 0.05 & 0.49 & 0.03 & 0.61 & $<0.03$ & 0.61 \\
\hline$<0.03$ & nd & $<0.03$ & 0.07 & $<0.03$ & $<0.03$ & $<0.03$ & $<0.03$ & 0.03 & 0.03 & nd & nd & nd & nd \\
\hline 99.73 & 100.3 & 99.36 & 98.72 & 98.89 & 99.10 & 99.43 & 99.43 & 99.11 & 99.30 & 99.27 & 99.27 & 98.76 & 99.05 \\
\hline 1.974 & 1.950 & 1.968 & 1.969 & 1.954 & 1.945 & 1.988 & 1.948 & 1.960 & 1.957 & 1.936 & 1.921 & 1.951 & 1.946 \\
\hline 0.017 & 0.050 & 0.032 & 0.031 & 0.046 & 0.050 & 0.012 & 0.046 & 0.040 & 0.043 & 0.016 & 0.048 & 0.019 & 0.046 \\
\hline 0.000 & 0.009 & 0.004 & 0.030 & 0.010 & 0.000 & 0.000 & 0.000 & 0.000 & 0.004 & 0.000 & 0.000 & 0.000 & 0.000 \\
\hline 0.004 & 0.006 & 0.014 & 0.006 & 0.006 & 0.006 & 0.005 & 0.006 & 0.003 & 0.003 & 0.002 & 0.006 & 0.002 & 0.006 \\
\hline 0.000 & 0.073 & 0.029 & 0.035 & 0.048 & 0.101 & 0.002 & 0.101 & 0.039 & 0.073 & 0.108 & 0.146 & 0.076 & 0.097 \\
\hline 0.368 & 0.304 & 0.350 & 0.304 & 0.343 & 0.300 & 0.370 & 0.305 & 0.195 & 0.178 & 0.197 & 0.171 & 0.191 & 0.184 \\
\hline 1.547 & 0.700 & 1.394 & 0.902 & 1.492 & 0.659 & 1.538 & 0.663 & 1.578 & 1.178 & 1.679 & 0.786 & 1.692 & 0.804 \\
\hline 0.056 & 0.024 & 0.042 & 0.027 & 0.053 & 0.022 & 0.052 & 0.020 & 0.029 & 0.015 & 0.029 & 0.018 & 0.036 & 0.016 \\
\hline 0.033 & 0.840 & 0.138 & 0.650 & 0.024 & 0.863 & 0.032 & 0.856 & 0.150 & 0.509 & 0.033 & 0.856 & 0.032 & 0.854 \\
\hline 0.001 & 0.044 & 0.028 & 0.043 & 0.022 & 0.054 & 0.002 & 0.055 & 0.005 & 0.040 & 0.000 & 0.048 & 0.001 & 0.047 \\
\hline 0.000 & nd & 0.001 & 0.003 & 0.002 & 0.000 & 0.001 & 0.000 & 0.001 & 0.000 & nd & nd & nd & nd \\
\hline 1.7 & 45.6 & 7.3 & 35.0 & 1.3 & 47.4 & 1.6 & 46.9 & 7.8 & 27.3 & 1.7 & 47.2 & 1.7 & 46.4 \\
\hline 18.9 & 16.4 & 18.7 & 16.4 & 18.5 & 16.4 & 19.2 & 16.8 & 10.1 & 9.5 & 10.3 & 9.4 & 9.9 & 9.9 \\
\hline 79.4 & 39.0 & 74.0 & 48.6 & 80.2 & 36.2 & 79.2 & 36.3 & 82.1 & 63.2 & 88.0 & 43.4 & 88.4 & 43.7 \\
\hline \multicolumn{2}{|c|}{1.826} & \multicolumn{2}{|c|}{1.342} & \multicolumn{2}{|c|}{1.980} & \multicolumn{2}{|c|}{1.912} & \multicolumn{2}{|c|}{1.223} & \multicolumn{2}{|c|}{1.854} & \multicolumn{2}{|c|}{2.027} \\
\hline
\end{tabular}
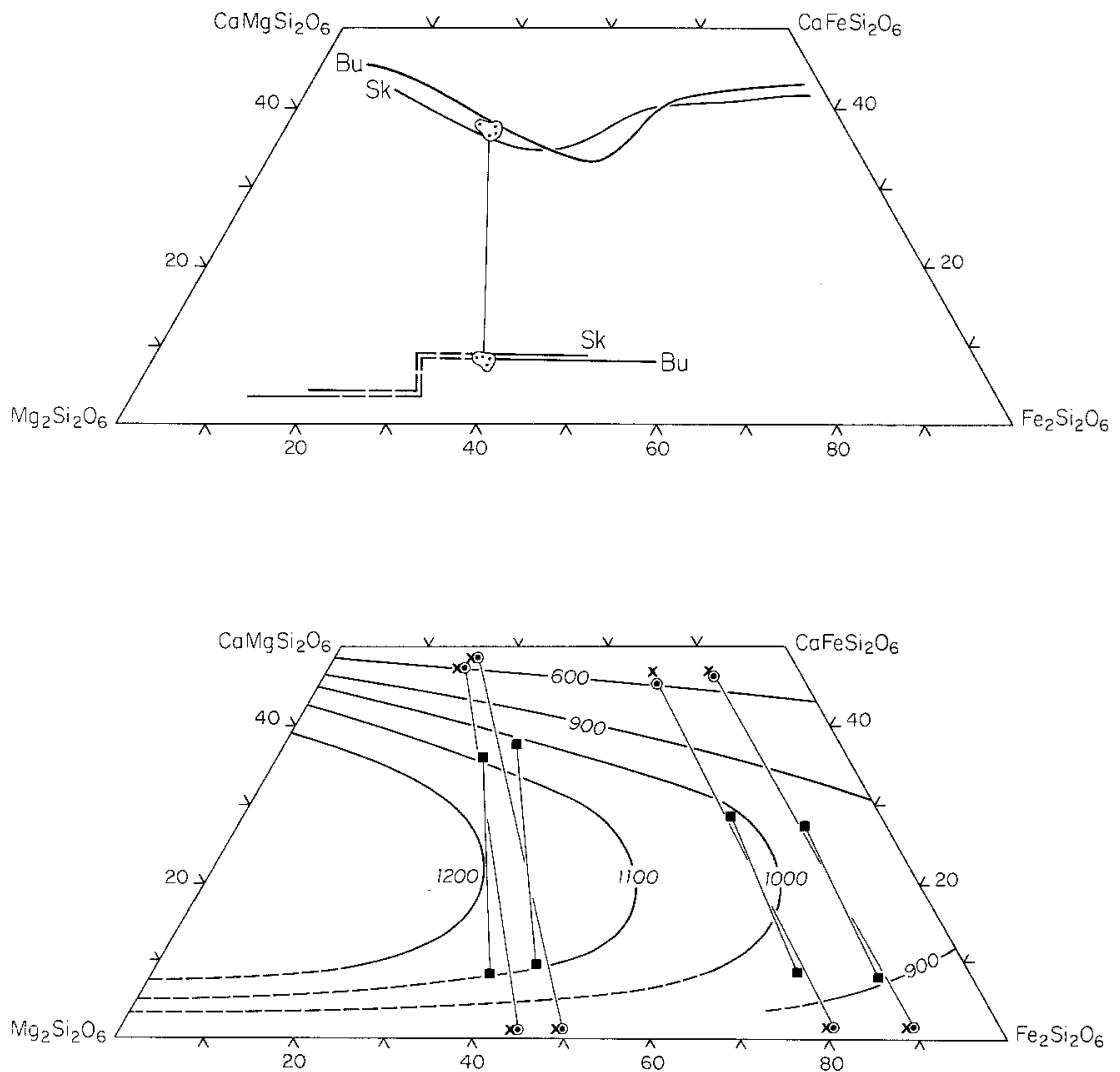

Fig. 3. Plot of reintegrated compositions of many grains of coarsely exsolved pyroxenes from the same rock are shown with respect to Bushveld and Skaergaard crystallization trends (data from Wager and Brown, 1968 and Atkins, 1969). The relatively small spread in the data is testament to the precision of careful microprobe reintegration

Fig. 4. Plot of coexisting coarsely exsolved pyroxenes (reintegrated compositions indicated by $(\boldsymbol{m})$, coexisting granular pyroxenes $(\odot)$, and exsolution lamellae in exsolved pyroxenes $(x)$ are plotted.

Groups of pyroxenes showing crossing tie lines are from the same rock 
and submicroscopic lamellae can result from spinodal decomposition, nucleation and growth (exsolution) or a combination of both. The composition of the lamellae as well as their crystal structure may be in part controlled by the particular unmixing mechanism. This may be of some importance in the unreversed homogenization experiments performed by Ross et al., (1973). If the pigeonite lamellae in the lunar pyroxenes were not formed solely by nucleation and growth involving an incoherent lattice boundary, the composition of the lamellae may have been affected by the unmixing process. Hence the homogenization temperatures may be in error. The RossHuebner solvus along the join $\mathrm{Fs}_{85} \mathrm{En}_{15}$-Wollastonite is also in some disagreement with the data of Smith (1972). Additionally, data on metamorphic temperatures (Bohlen and Essene, 1977) and coexisting pyroxenes in the Adirondacks (Fig. 5) and Australian granulites (Binns, 1962; Wilson, 1976) suggest that the augite limb of the solvus for iron-rich compositions should be widened slightly at low $\left(\approx 750^{\circ} \mathrm{C}\right)$ temperatures. This, of course, assumes that there was little or no postmetamorphic intercrystalline cation exchange. Regardless of the difficulties in estimating a complete pyroxene quadrilateral solvus, temperatures of equilibration for most pyroxene pairs can be estimated to within $100^{\circ} \mathrm{C}$. The reintegrated Adirondack pyroxene compositions yield high, igneous temperatures for equilibration of augite-pigeonite pairs in anorthosite, mangerite and charnockite which are consistent with their igneous textures. The data also indicate that the coarse exsolution lamellae within the pyroxenes last equilibrated at metamorphic temperature conditions. The small granular pyroxenes containing little or no exsolved material most likely formed during metamorphism and also yield metamorphic equilibration temperatures. The $K_{D}\left(\mathrm{Fe}^{2+} /\right.$ $\mathrm{Mg}$ ) values for the reintegrated pyroxene compositions are 1.2-1.3, well within Kretz's (1963) igneous range while the lamellae and metamorphic granular pyroxenes yield $K_{D}\left(\mathrm{Fe}^{2+} / \mathrm{Mg}\right)=1.8-2.4$, easily within Kretz's (1963) metamorphic range. Application of Wood-Banno (1973) thermometry to the reintegrated pyroxene compositions yields $1010^{\circ}, 940^{\circ}, 960^{\circ}$ and $910^{\circ}$ for LL-8 (anorthosite), 77-SL-2 (gabbro), IN-11 (mangerite) and SR-29 (charnockite) respectively. Although the calculated Wood-Banno temperatures appear to be $50^{\circ}-100^{\circ} \mathrm{C}$ low for anorthosite and gabbroic magmas, they are in fair agreement with temperatures inferred from the Ross-Huebner solvus. Regardless of the thermometer used, the temperatures obtained from the coexisting pigeonite-subcalcic augite pairs are igneous and are about $200^{\circ} \mathrm{C}$ higher than metamorphic temperatures obtained by oxide and feldspar thermometry (Bohlen and Essene, 1977).
These high temperatures require that the magma formed at low water pressures in order that high supersolidus temperatures be maintained.

Pyroxene compositions indicating magmatic temperatures of approximately $1100^{\circ} \mathrm{C}$ for anorthosite and associated gabbros are also consistent with coexisting pyroxene compositions from the Bushveld and Skaergaard as can be seen in Figure 6. Variations in reintegrated pyroxene compositions due to grain orientation and other analytical difficulties do not substantially change the results (see Fig. 3). Coexisting reintegrated pyroxenes from mangerite and charnockite (IN-11 and SR-29 respectively) differ from pigeonite-augite pairs of similar bulk composition from the contact aureole surrounding the Duluth Complex described by Bonnichsen (1969) and Simmons et al. (1974). The Adirondack pyroxenes define a narrower solvus gap indicating significantly higher equilibration temperatures. Metamorphic temperatures estimated for the contact aureole of the Duluth Complex are $700^{\circ}$ to $\geqq 800^{\circ} \mathrm{C}$ (Bonnichsen, 1969; Simmons et al., 1974). Maximum Adirondack metamorphic temperatures are $<800^{\circ} \mathrm{C}$. Therefore the coexisting iron-rich, reintegrated Adirondack pyroxenes could not have formed during metamorphism. The compositions are consistent with an igneous origin.

Figure 7 shows pyroxene data from a number of Grenville anorthosites and delineate a possible pyroxene crystallization trend for Grenville anorthosite massifs and associated rocks. In addition to data presented in this study (solid squares) data from the Morin and Lac St. Jean anorthosites (Philpotts, 1966-open squares; Emslie, 1975-circles) are also plotted. Coexisting ortho- and clinopyroxenes are connected by tie lines. The lack of pyroxenes between $\mathrm{Wo}_{10} \mathrm{En}_{55}-\mathrm{Wo}_{10} \mathrm{En}_{30}$ and $\mathrm{Wo}_{38} \mathrm{En}_{65}-\mathrm{Wo}_{35} \mathrm{En}_{50}$ may be important. If it is not simply an artifact of limited sampling, then a break in the pyroxene crystallization trend may indicate that mangerites and charnockites are not necessarily differentiates from an andesitic or high-Al basaltic magma (possible anorthosite parent magmas) but could represent another magma source. Clearly more data are necessary from rocks with approximately the proper bulk composition such as oxide gabbros and jotunites before the idea can be supported or rejected on the basis of pyroxene data.

The origins of mangerites and charnockites associated with anorthosite massifs has been greatly debated (for instance, Philpotts, 1966; Buddington, 1939). The pyroxene data presented in this paper constrain models on the formation of mangerites and charnockites in the Adirondacks. The data preclude formation of most of these rocks by in situ partial 

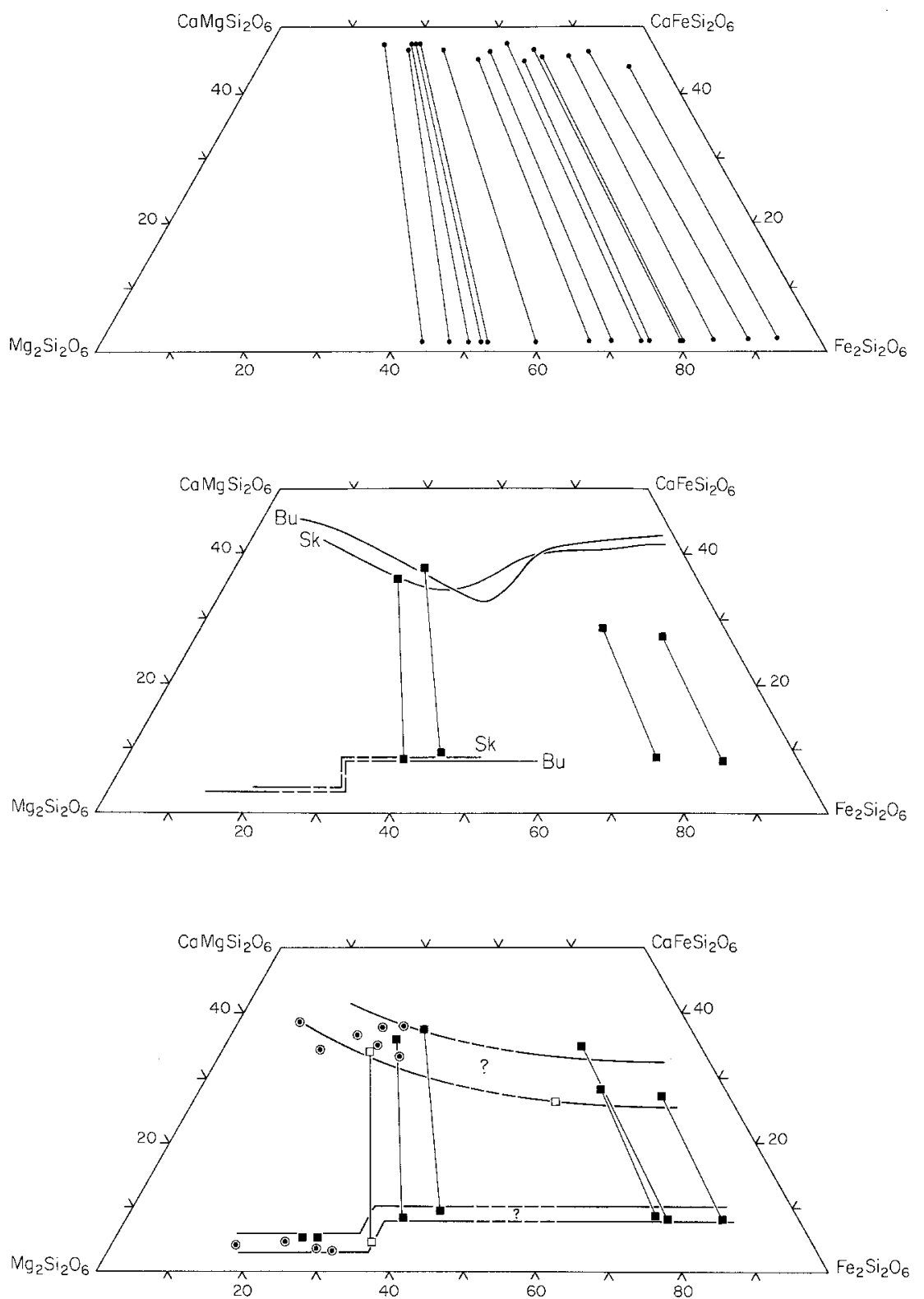

Fig. 5. Plot of coexisting metamorphic pyroxenes from the Adirondacks (unpublished data by Bohlen and Essene. Analyses available upon request).
Fig. 6. Comparison of reintegrated exsolved pyroxenes from the Adirondacks to pyroxene crystallization trends in Bushveld and Skaergaard intrusons. Data for layered intrusions from Wager and Brown (1968) and Atkins (1969)
Fig. 7. Possible pyroxene crystallization trend for Grenville anorthosites and related rocks. The width of the trend may represent partially reequilibrated pyroxenes, effect of additional components or errors in analysis. In addition to data from this study (a) data from Philpotts (1966) (ם) and Emslie (1975) (๑) are plotted melting due to the intrusion of anorthosite, because evidence of a high temperature metamorphic aureole around the anorthosite is lacking. The rocks could not have formed by regional metamorphic anatexis because metamorphic temperatures (Bohlen and Essene, 1977) were some $200^{\circ} \mathrm{C}$ lower than temperatures inferred from coexisting pigeonite-subcalcic augite. Finally, most Adirondack mangerites and charnockites could not have formed by progressive dehydration of country rocks during granulite facies metamorphism because metamorphic temperatures were too low. In addition to limiting temperatures of crystallization, the chemistry of the phenocrysts are important for understanding the origins of igneous rocks.
For anorthosites there is little agreement even now in the composition or origin of the parent magma from which anorthosite accumulated. Careful analysis of phenocrysts may yield additional information restricting hypotheses.

Adirondack orthopyroxene megacrysts, one with and one without plagioclase exsolution lamellae, have been plotted in Figure 7. These megacrysts are not only distinctive in size but in their chemistry as well (analyses are compiled in Table 2). To date no matrix pyroxenes have been found in the Adirondack Highlands which are as magnesian as these relatively uncommon pyroxene megacrysts. Emslie (1975) and Morse (1975) have also described pyroxene mega- 
Table 2. Pyroxene megacrysts and plagioclase

\begin{tabular}{|c|c|c|c|c|c|}
\hline & $\begin{array}{l}\text { Integrated } \\
\text { megacryst } \\
\text { w/ plag } \\
\text { lamellae }\end{array}$ & $\begin{array}{l}\text { Integrated } \\
\text { megacryst } \\
\text { w/o plag } \\
\text { lamellae }\end{array}$ & & $\begin{array}{l}\text { Plag } \\
\text { lamellae } \\
\text { in } \\
\text { megacryst }\end{array}$ & $\begin{array}{l}\text { Host } \\
\text { rock } \\
\text { plag }\end{array}$ \\
\hline $\mathrm{SiO}_{2}$ & 51.60 & 52.60 & $\mathrm{SiO}_{2}$ & 46.73 & 55.12 \\
\hline $\mathrm{TiO}_{2}$ & 0.28 & 0.39 & $\mathrm{Al}_{2} \mathrm{O}_{3}$ & 34.23 & 29.01 \\
\hline $\mathrm{Al}_{2} \mathrm{O}_{3}$ & 5.71 & 3.64 & $\mathrm{CaO}$ & 17.32 & 11.22 \\
\hline $\mathrm{FeO}^{*}$ & 16.97 & 16.84 & $\mathrm{BaO}$ & $<0.03$ & $<0.03$ \\
\hline $\mathrm{MnO}$ & 0.20 & 0.22 & $\mathrm{Na}_{2} \mathrm{O}$ & 1.64 & 5.29 \\
\hline $\mathrm{MgO}$ & 22.57 & 24.42 & $\mathrm{~K}_{2} \mathrm{O}$ & 0.03 & 0.19 \\
\hline $\mathrm{CaO}$ & 2.76 & 2.70 & SUM & 99.96 & 100.7 \\
\hline $\mathrm{Na}_{2} \mathrm{O}$ & 0.32 & 0.05 & & & \\
\hline $\mathrm{K}_{2} \mathrm{O}$ & $<0.03$ & $<0.03$ & & & \\
\hline SUM & 100.4 & 100.9 & & & \\
\hline $\mathrm{Si}$ & 1.874 & 1.898 & $\mathrm{Si}$ & 2.147 & 2.467 \\
\hline $\mathrm{Al}$ & 0.126 & 0.102 & $\mathrm{Al}$ & 1.853 & 1.533 \\
\hline $\mathrm{Al}$ & 0.119 & 0.053 & $\mathrm{Ca}$ & 0.853 & 0.533 \\
\hline $\mathrm{Ti}$ & 0.008 & 0.011 & $\mathrm{Ba}$ & 0.000 & 0.000 \\
\hline $\mathrm{Fe}^{3+}$ & 0.013 & 0.030 & $\mathrm{Na}$ & 0.146 & 0.455 \\
\hline $\mathrm{Mg}$ & 1.222 & 1.314 & $\mathrm{~K}$ & 0.001 & 0.011 \\
\hline $\mathrm{Fe}^{2+}$ & 0.503 & 0.478 & $\mathrm{AN}$ & 85 & 54 \\
\hline $\mathrm{Mn}$ & 0.006 & 0.007 & & & \\
\hline $\mathrm{Ca}$ & 0.107 & 0.104 & & & \\
\hline $\mathrm{Na}$ & 0.022 & 0.003 & & & \\
\hline $\mathrm{K}$ & 0.000 & 0.000 & & & \\
\hline Wo & 5.8 & 5.5 & & & \\
\hline En & 66.7 & 69.3 & & & \\
\hline Fs & 27.5 & 25.2 & & & \\
\hline
\end{tabular}

crysts with plagioclase exsolution lamellae in other anorthosite massifs. The exsolution of plagioclase alone from a pyroxene requires that the original pyroxene be non-stoichiometric, that other phases be involved in exsolution or that the exsolution process be metasomatic. The writers' and Emslie's (1975) data for reintegrated anorthosite pyroxene megacrysts indicate that the original aluminous pyroxene was approximately stoichiometric $\mathrm{R}_{4} \mathrm{O}_{6}$ pyroxene. The exsolved plagioclase is typically more anorthitic than An 80. Possible isochemical exsolution reactions are:

anorthite component:

$3 \mathrm{CaAl}_{2} \mathrm{Si}_{2} \mathrm{O}_{8}+\mathrm{Fe}_{3} \mathrm{O}_{4}$

$=3 \mathrm{CaAl}_{2} \mathrm{SiO}_{6}+3 \mathrm{FeSiO}_{3}+1 / 2 \mathrm{O}_{2}$;

albite component:

$6 \mathrm{NaAlSi}_{3} \mathrm{O}_{8}+3 \mathrm{Fe}_{3} \mathrm{O}_{4}$

$=3 \mathrm{FeAl}_{2} \mathrm{SiO}_{6}+6 \mathrm{NaFeSi}_{2} \mathrm{O}_{6}+3 \mathrm{FeSiO}_{3}+1 / 2 \mathrm{O}_{2}$.

These schematic reactions require that magnetite is involved in the exsolution with plagioclase in rough accordance with observation. The required modal ratio of plagioclase to magnetite is roughly 7 to 1 which is also in agreement with observation in many, though not all, pyroxene megacrysts seen thus far. Other reactions involving quartz, Ca-Tschermaks, jadeite and plagioclase have been written and discussed by Morse (1975).
A number of hypotheses have been proposed to explain the pyroxene megacrysts. Emslie (1975) explains these high-Al pyroxenes as intratelluric megacrysts crystallizing at high $(15 \pm 5 \mathrm{~kb})$ pressures. Alternatively Morse (1975b) proposes that these megacrysts grew rapidly as metastable high-Al phases under supersaturated conditions, analogous to some lunar pyroxenes. However, we believe that the data are also consistent with liquidus growth of pyroxene in equilibrium with a plagioclase-rich melt at crustal pressures and high temperatures. High Tschermaks component in the pyroxene can be favored by high temperature and is not solely a response to pressure or to metastable growth. In addition, the presence of olivine (Fo 81) inclusions in a few megacrysts (Emslie, 1975-Harp Lake EC72-56A) restricts pressures to relatively low values if it crystallized in equilibrium with an anorthositic magma in which the activity of anorthite was high. For the end-member system, forsterite-anorthite are restricted to below $8 \mathrm{~kb}$ for a wide temperature range (Kushiro and Yoder, 1966). Impurities such as $\mathrm{Na}$ and $\mathrm{Fe}$ components in plagioclase and olivine respectively would favor the lowpressure assemblage and careful modeling of these components and magmatic anorthite and silica activities is required before the formation pressures can be precisely evaluated. Clearly more data are necessary to distinguish mechanisms for high-Al pyroxene megacryst growth. The choice of the model is of major importance in anorthosite genesis.

If anorthosite megacrysts crystallized in equilibrium with a magma on or near the dry liquidus, their compositions constrain the bulk composition from which they crystallized. The distribution of $\mathrm{Fe}^{2+}$ and $\mathrm{Mg}$ between the melt and phenocrysts can be estimated for mafic (i.e., basalt and andesite) compositions from natural occurrences (Smith and Carmichael, 1968) and experiments (Green and Ringwood, 1967; Huebner et a1., 1976; Lipin, 1976). Estimated $K_{D \text { opx }}^{\text {melt }}$ from these data range from 2.5-3.5. Assuming the $K_{D \text { opx }}^{\text {melt }} \approx 3$, the compositions of the megacrysts from the Adirondacks require an $\mathrm{MgO} / \mathrm{FeO}$ wt $\% \mathrm{ra}-$ tio in the primary magma of about $1 / 2.2$. The bulk composition of the entire Adirondack syenite-gabbroanorthosite series has been estimated by Buddington (1939) and has an $\mathrm{MgO} / \mathrm{FeO}$ wt $\%$ ratio of $1 / 4$ which appears to be too iron-rich to be the primary magma with which the high-Al megacrysts equilibrated. Andesitic, gabbroic anorthosite and certain high-Al basaltic magmas could possibly fit the required $\mathrm{Mg} / \mathrm{Fe}$ ratios. These data are consistent with laboratory experiments (Green, 1969) which indicate that andesite, high-Al basalt or gabbroic anorthosite, under proper conditions, can give rise to anorthosite with pyroxenes as liquidus or near-liquidus phases. 
In studies on the origin of anorthosite Green (1969) analyzed a near liquidus orthopyroxene in equilibrium with an original quartz diorite (andesite) bulk composition. His calculated $K_{D \text { opx }}^{\text {melt }}$ of 11 is at variance with many natural and experimental assemblages. Assuming that the natural assemblages give a realistic $K_{D \text { Fe-Mg }}^{\text {melt-opx }}=3$ and back-calculating from the pyroxene, the required $\mathrm{MgO} / \mathrm{FeO}$ wt \% ratio of pyroxene to liquid is roughly $1 / 1$, quite different from Green's initial starting composition of $1 / 2.5$. These data suggest that the synthetic pyroxene equilibrated with a more magnesian liquid than the starting composition. There may have been a problem with iron loss and/or oxidation if platinum capsules were used in Green's experiments.

\section{Conclusion}

Pyroxene data from the Adirondacks are consistent with the crystallization of liquidus pyroxenes in equilibrium with a dry basaltic andesite, high-Al basalt or gabbroic anorthosite magma perhaps at relatively high levels in the crust. Crystallization of the magma produced ophitic to subophitic textures in anorthosite The re-equilibration of phenocrysts to metamorphic compositions suggests that the magma intruded preor syn-tectonically with the Grenville event. Pyroxenes crystallizing late yield igneous temperatures of about $1100^{\circ} \mathrm{C}\left( \pm 100^{\circ} \mathrm{C}\right)$ in anorthosite when exsolution lamellae are carefully reintegrated. The pyroxene data alone do not indicate whether the mangerites and charnockites are cogenetic members of an anorthosite suite. However, the data do show that most mangerites and charnockites in the Adirondacks were igneous in origin. The high minimum magmatic temperatures for all rock types suggest that they formed and crystallized under relatively dry $P\left(\mathrm{H}_{2} \mathrm{O}\right) \ll P$ (solid) conditions to maintain high supersolidus temperatures. The presence of inverted pigeonites and coexisting subcalcic augites preclude the possibility of mangerite and charnockite formation by in situ partial melting due to intrusion of anorthosite, by regional metamorphic anatexis or by progressive dehydration of country rocks during granulite facies metamorphism. The data from exsolution lamellae in igneous pyroxenes and recrystallized granular pyroxenes indicate that all Adirondack pyroxenes last equilibrated during a granulite facies metamorphic event. Metamorphism of dry rocks would allow preservation of unannealed or only partially annealed textures. Thus careful reintegration of the pyroxene exsolution lamellae provides a window through the metamorphic event in the Adirondack Highlands.

Acknowledgments. The writers are thankful for the support of $\mathrm{Na}$ tional Science Foundation Grant No. 014573 to EJE, GSA Penrose
Grant No. 2003-75 to SRB and the Turner Fund of The University of Michigan. The electron microprobe facilities at The University of Michigan are supervised by Professor Wilbur C. Bigelow of the department of Metallurgy and Material Science whose cooperation made this study possible. Several members of his staff particularly L.F. Allard, P.J. Hollingsworth and A.J. Mardingly gave valuable assistance during data collection. The writers wish to thank Dr. D.R. Peacor and Dr. W.C. Kelly of the Department of Geology and Mineralogy, University of Michigan for their critical reviews of the manuscript. We also thank Malcolm Ross, Stephen Huebner and John Grover for stimulating discussions which clarified our view of pyroxene thermometry. The writers give special thanks to Ron Emslie of the Geological Society of Canada for kindly providing many excellent specimens of pyroxene megacrysts. Mr. Derwin Bell drafted the line drawings which appear in this report.

\section{Appendix I: Sample Location}

LL-8 Near Rt. 3-Long Lake Quadrangle. 0.75 miles east of Upper Saranac Lake, south of summit of hill 2044.

77-SL-2 May Road 0.5 miles north of McCauley Pond, Saranac Lake Quadrangle.

IN-11 0.2 miles west of Rt. 30,1 mile south of Sabael, Indian Lake Quadrangle.

P-10 3.0 miles southwest of Sacandaga Lake along Rt. 8, Piseco Lake Quadrangle.

SR-29 0.5 miles south of Lead Pond, Saint Regis, Quadrangle.

77-MM-1 Elevation approximately $2900 \mathrm{ft}$. along east gully of Cascade Slide, Mount Marcy Quadrangle.

Appendix II: Repeated Pyroxene Analyses

\begin{tabular}{|c|c|c|c|c|c|c|}
\hline & $\begin{array}{l}\text { LL-8 a } \\
\text { Intg. } \\
\text { Opx }\end{array}$ & $\begin{array}{l}\text { LL-8 a } \\
\text { Intg. } \\
\text { Cpx }\end{array}$ & $\begin{array}{l}\text { LL- } 8 b \\
\text { Intg. } \\
\text { Opx }\end{array}$ & $\begin{array}{l}\text { LL-8b } \\
\text { Intg. } \\
\text { Cpx }\end{array}$ & $\begin{array}{l}\text { LL-8-1 } \\
\text { Intg. } \\
\text { Opx }\end{array}$ & $\begin{array}{l}\text { LL-8-1 } \\
\text { Intg. } \\
\text { Cpx }\end{array}$ \\
\hline $\mathrm{SiO}_{2}$ & 50.31 & 49.43 & 50.27 & 50.55 & 50.97 & 50.49 \\
\hline $\mathrm{TiO}_{2}$ & 0.31 & 0.77 & 0.31 & 0.22 & 0.31 & 0.52 \\
\hline $\mathrm{Al}_{2} \mathrm{O}_{3}$ & 1.90 & 3.02 & 1.81 & 2.61 & 2.07 & 2.84 \\
\hline $\mathrm{FeO} *$ & 23.69 & 15.07 & 23.65 & 15.47 & 23.66 & 15.17 \\
\hline $\mathrm{MnO}$ & 0.48 & 0.24 & 0.46 & 0.30 & 0.41 & 0.23 \\
\hline $\mathrm{MgO}$ & 18.88 & 12.97 & 18.85 & 12.70 & 18.59 & 12.55 \\
\hline $\mathrm{CaO}$ & 3.90 & 17.36 & 3.90 & 16.92 & 3.60 & 17.09 \\
\hline $\mathrm{Na}_{2} \mathrm{O}$ & $<0.03$ & 0.43 & $<0.03$ & 0.52 & $<0.03$ & 0.38 \\
\hline $\mathrm{K}_{2} \mathrm{O}$ & $<0.03$ & $<0.03$ & $<0.03$ & $<0.03$ & $<0.03$ & $<0.03$ \\
\hline SUM & 99.49 & 99.30 & 99.27 & 99.30 & 99.63 & 99.28 \\
\hline $\mathrm{Si}$ & 1.911 & 1.880 & 1.913 & 1.925 & 1.935 & 1.926 \\
\hline $\mathrm{Al}$ & 0.085 & 0.120 & 0.081 & 0.075 & 0.065 & 0.074 \\
\hline $\mathrm{Al}$ & 0.000 & 0.016 & 0.000 & 0.042 & 0.028 & 0.054 \\
\hline $\mathrm{Ti}$ & 0.009 & 0.022 & 0.009 & 0.006 & 0.009 & 0.015 \\
\hline $\mathrm{Fe}^{3+}$ & 0.076 & 0.093 & 0.076 & 0.061 & 0.019 & 0.018 \\
\hline $\mathrm{Mg}$ & 1.069 & 0.735 & 1.069 & 0.721 & 1.052 & 0.714 \\
\hline $\mathrm{Fe}^{2+}$ & 0.676 & 0.386 & 0.677 & 0.432 & 0.732 & 0.466 \\
\hline $\mathrm{Mn}$ & 0.015 & 0.008 & 0.015 & 0.010 & 0.013 & 0.007 \\
\hline $\mathrm{Ca}$ & 0.158 & 0.707 & 0.159 & 0.690 & 0.147 & 0.698 \\
\hline $\mathrm{Na}$ & 0.001 & 0.032 & 0.001 & 0.038 & 0.000 & 0.028 \\
\hline $\mathrm{K}$ & 0.001 & 0.001 & 0.000 & 0.000 & 0.000 & 0.000 \\
\hline Wo & 8.3 & 38.7 & 8.3 & 37.4 & 7.6 & 37.2 \\
\hline En & 56.2 & 40.2 & 56.1 & 39.1 & 54.5 & 38.0 \\
\hline Fs & 35.5 & 21.1 & 35.6 & 23.5 & 37.9 & 24.8 \\
\hline $\mathrm{K}_{D}$ & 1.204 & & 1.057 & & 1.066 & \\
\hline
\end{tabular}




\section{References}

Atkins, F.B.: Pyroxenes of the Bushveld intrusion, South Africa. J. Petrol. 10, 229-249 (1969)

Binns, R.A. : Metamorphic pyroxenes from the Broken Hill district, New South Wales. Mineral. Mag. 33, 320-338 (1962)

Bohlen, S.R., Essene, E.J.: Feldspar and oxide thermometry of granulites in the Adirondack Highlands. Contrib. Mineral. Petrol. 62, 153-169 (1977)

Bonnichsen, B.: Metamorphic pyroxenes and amphiboles in the Biwabik Iron Formation, Dunka River Area, Minnesota. Mineral. Soc. Am. Spec. Papers. 2, 217-239 (1969)

Buddington, A.F.: Adirondack igneous rocks and their metamorphism. Geol. Soc. Am. Mem. 7, p. 354 (1939)

Davidson, L.R.: Variation in ferrous iron-magnesium distribution coefficients of metamorphic pyroxenes from Quairading, Western Australia. Contrib. Mineral. Petrol. 19, 239-259 (1968)

Davis, B.T.C., Boyd, F.R.: The join $\mathrm{Mg}_{2} \mathrm{Si}_{2} \mathrm{O}_{6}-\mathrm{CaMgSi}_{2} \mathrm{O}_{6}$ at 30 kilobars pressure and its application to pyroxenes from kimberlites. J. Geophys. Res. 71, 3567-3576 (1966)

Emslie, R.F.: Pyroxene megacrysts from anorthositic rocks: new clues to the sources and evolution of the parent magmas. Can. Mineralogist 13, 138-145 (1975)

Engel, A.E.J., Engel, C.G.: Progressive metamorphism of amphibolites, northwest Adirondack Mountains, New York: Geol. Soc. Am. Buddington Volume, 37-82 (1962a)

Green, T.H.: High-pressure experimental studies on the origin of anorthosite. Can. J. Earth Sci. 6, 427-440 (1969)

Green, T.H., Ringwood, A.E.: Crystallization of basalt and andesite under high pressure hydrous conditions. Earth Planet. Sci. Lett. 3, 481-489 (1967)

Grover, J.E., Lindsley, D.H., Turnock, A.C.: Ca-Mg-Fe pyroxenes: subsolidus phase relations in iron-rich portions of the pyroxene quadrilateral. Geol. Soc. Am. Abstr. with Program 4, 521-522 (1972)

Huebner, J.S., Lipin, B.R., Wiggins, L.B. : Partitioning of chromium between silicate crystals and melts. Proc. Lunar Sci. Conf. 7, 1195-1220 (1976)

Jaffe, H.W., Robinson, P., Tracy, R.J., Ross, M.: Orientation of pigeonite exsolution lamellae in metamorphic augite: correlation with composition and calculated optimal phase boundaries. Am. Mineralogist 60, 9-28 (1975)

Kretz, R.: Distribution of magnesium and iron between orthopyroxene and calcic pyroxene in natural mineral assemblages. J. Geol. 71, 773-785 (1963)

Kushiro, J.: Determination of liquidus relations in synthetic silicate systems with electron probe analysis: the system forsterite-diopside-silica at 1 atmosphere. Am. Mineralogist 57, 1260-1271 (1972b)

Kushiro, J., Yoder, H.S.: Anorthite-forsterite and anorthite-enstatite reactions and their bearing on the basalt-eclogite transformation. J. Petrol. 7, 337-362 (1966)

Lindsley, D.H., Grover, J.E., Calabro, C.E.: Subsolidus phase relations of $\mathrm{Ca}-\mathrm{Mg}-\mathrm{Fe}$ pyroxenes with $\mathrm{Fe} / \mathrm{Fe}+\mathrm{Mg}$ near 0.75 at pressures from $1-5 \mathrm{kbar}$ and temperatures from $600-800^{\circ} \mathrm{C}$. Geol. Soc. Am. Abstr. with Program 5, 713-714 (1973)

Lindsley, D.H., King, H.E., Jr., Turnock, A.C.: Phase relations in the pyroxene quadrilateral at $980^{\circ} \mathrm{C}$ and $15 \mathrm{kbar}$. Geol. Soc. Am. Abstr. with Program 6, 846-847 (1974)

Lindsley, D.H., King, H.E., Jr., Turnock, A.C.: Compositions of synthetic augite and hypersthene coexisting at $810^{\circ} \mathrm{C}$ : application to pyroxenes from lunar highlands rocks. Geophys. Res. Lett. 1, 134-136 (1974)
Lindsley, D.H., Munoz, J.L.: Subsolidus relations along the join hedenbergite-ferrosilite. Am. J. Sci. 267A, 295-324 (1969)

Lipin, B.R.: The origin of Fra Mauro basalts. Proc. Lunar Sci. Conf. 7 Abst., 495-497 (1976)

Mori, T., Green, D.H. : Pyroxenes in the system $\mathrm{Mg}_{2} \mathrm{Si}_{2} \mathrm{O}_{6}$-CaMg$\mathrm{Si}_{2} \mathrm{O}_{6}$ at high pressure. Earth Planet. Sci. Lett. 26, 277-286 (1975)

Morse, S.A.: Plagioclase lamellae in hypersthene, Tikkoatokhakh Bay, Labrador. Earth Planet. Sci. Lett. 26, 331-336 (1975)

Morse, S.A.: High-Al pyroxene in anorthosite: barometer or speedometer? International Conf. Geotherm. Geobarom., Extended Abstracts, Penn. St. Univ. (1975)

Nehru, C.E., Wyllie, P.J.: Electron microprobe measurement of pyroxenes coexisting with $\mathrm{H}_{2} \mathrm{O}$-undersaturated liquid in the join $\mathrm{CaMgSi}_{2} \mathrm{O}_{6}-\mathrm{Mg}_{2} \mathrm{Si}_{2} \mathrm{O}_{6}-\mathrm{H}_{2} \mathrm{O}$ at 30 kilobars, with applications to geothermometry. Contrib. Mineral. Petrol. 48, 221-228 (1974)

Philpotts, A.R. : Origin of the anorthosite-mangerite rocks in southern Quebec. J. Petrol. 7, 1-64 (1966)

Ross, M., Huebner, J.S.: A pyroxene geothermometer based on composition-temperature relationships of naturally occurring orthopyroxene, pigeonite, and augite. International Conf. Geotherm. Geobarom. Extended Abstracts, Penn. St. Univ. (1975)

Ross, M., Huebner, J.S. Dowty, E.: Delineation of the one atmosphere augite-pigeonite miscibility gap for pyroxenes from lunar basalt 12021. Am. Mineralogist 58, 619-635 (1973)

Rucklidge, J.C., Gasparrini, E.L.: Specifications of a complete program for processing electron microprobe data: EMPADR VII. Dept. of Geology, Univ. of Toronto, unpublished circular (1969)

Simmons, E.C., Lindsley, D.H., Papike, J.J.: Phase relations and crystallization sequence in a contact metamorphosed rock from the Gunflint Iron Formation, Minnesota. J. Petrol. 15, 539-565 (1974)

Smith, A.L., Carmichael, I.S.E.: Quaternary lavas from the Southern Cascades, Western U.S.A. Contrib. Mineral. Petrol. 19, 212-238 (1968)

Smith, D.: Stability of iron-rich pyroxene in the system $\mathrm{CaSiO}_{3}$ $\mathrm{FeSiO}_{3}-\mathrm{MgSiO}_{3}$. Am. Mineralogist 57, 1413-1428 (1972)

Wager, L.R., Brown, G.M. : "Layered Igneous Rocks", Freemont, San Francisco (1967)

Warner, R.D., Luth, W.C.: The diopside-orthoenstatite two-phase region in the system $\mathrm{CaMgSi}_{2} \mathrm{O}_{6}-\mathrm{Mg}_{2} \mathrm{Si}_{2} \mathrm{O}_{6}$. Am. Mineralogist 59, 98-109 (1974)

Wilson, A.L.: Aluminum in coexisting pyroxenes as a sensitive indicator or changes in metamorphic grade within the mafic granulite terrane of the Fraser Range, Western Australia. Contrib. Mineral. Petrol. 56, 255-277 (1976)

Wood, B.J.: The influence of pressure, temperature and bulk composition on the appearance of garnet in orthogneisses-an example from South Harris, Scotland. Earth Planet. Sci. Lett. 26, 299-311 (1975)

Wood, J.S., Banno, S.: Garnet-orthopyroxene and orthopyroxeneclinopyroxene relationships in simple and complex systems. Contrib. Mineral. Petrol. 42, 109-124 (1973)

Yang, H.-Y.: Crystallization of iron-free pigeonite in the system anorthite-diopside-enstatite-silica at atmospheric pressure. Am. J. Sci. 273, 488-497 (1973)

Received September 1, 1977 / Accepted October 20, 1977 